\title{
ЗБОРОРЕДОТ ВО ПРОСТАТА РЕЧЕНИЦА: ИНВЕРЗИЈА НА СУБЈЕКТОТ И ПРЕДИКАТОТ
}

\author{
Елени Бужаровска \\ Универзитет „Св. Кирил и Методиј“, Скопје \\ elenibuzarovska@t.mk
}

Лилјана Митковска

Универзитет ФОН, Скопје

liljana.mitkovska@fon.edu.mk

\author{
Анастазија Киркова-Наскова \\ Универзитет „Св. Кирил и Методиј“, Скопје \\ akirkova@flf.ukim.edu.mk
}

\begin{abstract}
Во овој труд се разгледува феноменот инверзија на субјектот во македонскиот јазик како пример за збороред што зависи од прагматичкото значење на реченицата. Дискусијата претставува анализа на заемната интеракција на повеќе фактори на семантичко, синтаксичко и дискурсно ниво, кои резултираат со појава на постглаголски субјекти со неакузативни глаголи на реченично и на дискурсно ниво. Користејќи примери од јазичен примерок од повеќе видови пишани извори (книжевни, академски и популарни текстови), авторите посочуваат дека инверзијата на субјектот и предикатот се јавува кај конструкции што се презентациски или реченици-случки, кои воведуваат нов партиципант или нова случка во текстот. Резултатите од анализата ја потврдуваат основната хипотеза дека е инверзијата резултат на заемната интеракција на прагматичките функции на реченично и на текстуално ниво. Маркираната информациска структура повлекува инверзија доколку исполнува кохезивна функција во текстот. Во книжевните текстови, инверзијата има дополнителна прагматичка функција, така што му припишува тематски статус на субјектниот референт и предизвикува ефект на очевидност при опишувањето на ситуацијата.
\end{abstract}

Клучни зборови: информациска структура, инверзија, субјект, неакузативни глаголи, презентациски конструкции 


\title{
WORD ORDER IN SIMPLE SENTENCES: SUBJECT AND PREDICATE INVERSION
}

\author{
Eleni Bužarovska
}

Ss. Cyril and Methoduis University, Skopje

elenibuzarovska@t.mk

Liljana Mitkovska

FON University, Skopje

liljana.mitkovska@fon.edu.mk

Anastazija Kirkova-Naskova

Ss. Cyril and Methoduis University, Skopje

akirkova@flf.ukim.edu.mk

The paper investigates the phenomenon of inverted subjects in Macedonian as an instance of a word order governed by pragmatics. It presents an analysis of semantic, syntactic and discourse interface that produces postverbal subjects with unaccusative verbs at sentence and discourse level. Using evidence from a sample of collected examples from different written sources (literary, academic and popular texts) the authors show that subject-verb inversion occurs in presentative and eventive constructions which introduce a new referent or a new event into the discourse. The results of the analysis confirm the main hypothesis that inversion results from the interplay of pragmatic principles at a sentence and discourse level. The marked information structure triggers inversion if it fulfills a cohesive function in the discourse. In literary texts, inversion serves an additional pragmatic function as it assigns a topical status to the subject referent and creates an eye-witness effect in presenting the described situation

Keywords: information structure, inversion, subject, unaccusative verbs, presentative constructions 


\section{1 Вовед}

Предмет на нашиот интерес се речениците од типот: Во хояникой сӣоеше еоно момче, кои се одликуваат со непрототипна реченична линеаризација. За разлика од речениците со немаркиран збороред, во кои субјектот стои пред (глаголскиот) предикат, во овие реченици субјектот следува по нетранзитивниот глагол. Таквата промена на местото на субјектот во проста реченица ја нарекуваме субјектна инверзија.

Јазиците со прототипна линеаризација Субјект + Предикат + Објект (како што се индоевропските) може да се поделат според тоа во која мера дозволуваат варијации во линеаризацијата на реченичните конституенти: некои јазици имаат пофлексибилен збороред, наспроти јазиците со построг, фиксен збороред. Првите имаат прагматички, а вторите - граматички збороред (Rutherford 1989). Македонскиот јазик, како и другите словенски и некои несловенски јазици (шпанскиот, италијанскиот, грчкиот, албанскиот и др.), се одликува со прагматички збороред, кој е под влијание на информациската структура надградена над синтаксичкото ниво. Немаркираната информациска структура го следи принципот на природното процесирање на информацијата, според кој говорителот вообичаено го структурира исказот почнувајќи од позната информација, на која се надоврзува новата. ${ }^{1}$ Така, позната, односно „стара“ информација (тема), стои на почетокот на реченицата, а новата информација (рема) следува по неа, бидејќи е когнитивно потешка за процесирање. Отстапувањето од немаркираната информациска структура влијае врз синтаксата на простата реченица, како на пример, во случај на субјектната инверзија.

Во статијата ги испитуваме овие теориски поставки врз македонски материјал. Сакаме да покажеме дека морфосинтаксичките појави може да се објаснат преку информациска и прагматичка перспектива. Сметаме дека инверзијата се јавува како резултат на прагматичката функција на реченицата во дискурсот и затоа треба да се гледа во поширок контекст. Прагматичките фактори влијаат на две нивоа: реченично и текстуално. Во фактори што влијаат на ниво на реченицата спаѓа дискурсниот статус на аргументот во реченицата (дали е првпат споменат во дадениот дискурс), кој е во корелација со семантиката на глаголот. Под дискурсни фактори на текстуално ниво ја подразбираме функцијата на реченицата со инверзија во текстот и нејзините релации со претходниот и последователниот текст.

Речениците со обратна, односно непрототипна линеаризација имаат специфична улога во дискурсот, бидејќи воведуваат нов партиципант во текстот. Таа функција е позната како презентациска, бидејќи има посебна комуникативна цел - да го претстави новиот протагонист, кој ќе биде тема понатаму во дискурсот (Downing and Locke 2006: 257, Givón 2001: 255, Quirk et al. 1985: 522).

\footnotetext{
${ }^{1}$ Natural Information Flow (Comrie 1989: 127-128).
} 
За илустрација го даваме примерот (1) од интервју со човекот што се грижи за жирафите во зоолошката градина. На прашањето како се стекнал со популарност, тој одговара со раскажување на една случка. По првата реченица што ја воведува темата на раскажувањето, следуваат две последователни реченици во кои се воведува времето на случката (викеня) и главниот протагонист (Горан). Во третата реченица се воведува нов предмет (фойог̄рафии).

Сѐ беше сосема случајно, не очекував яека ќе сиианеме йолку йойуларни. Беше сосема обичен викеня, оојое мојой иријаиелл Горан со

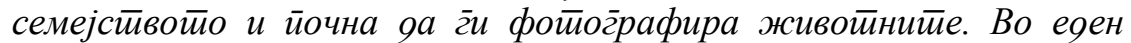

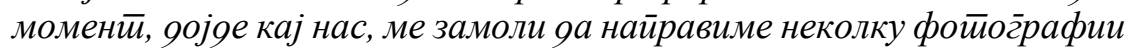
на иито јас се сог̄ласив и сосема случајно излегоо сиие ииие фойогрpaфuu. (fashionel.mk/intervjua)

Во оваа статија ги разгледуваме презентациските реченици. Основната хипотеза од која поаѓаме е дека синтаксичката инверзија на субјектот и предикатот во презентациските реченици има прагматичка мотивација. Претпоставуваме дека инверзијата се случува во речениците каде што комуникациски се истакнува субјектот. Таквото истакнување создава конфликт меѓу синтаксата и прагматиката на презентациската реченица, односно несовпаѓање со нејзината информациска структура. Имено, тие немаат немаркирана информациска структура тема - рема, бидејќи единствениот протагонист во субјектна позиција не носи стара информација. Расчекорот меѓу дискурсниот и синтаксичкиот статус на субјектниот референт доведува до инверзија на субјектот. Треба да се истакне дека самата презентациска конструкција ги граматикализира семантичката и прагматичката улога на партиципантот и така ги наметнува постојните граматички релации.

Предмет на анализата во статијата ќе бидат реченици со субјектна инверзија градени со посебен тип непреодни глаголи (т.н. неакузативни) и пасивни перифрастични и се-конструкции. Нема да ги обработуваме примерите на инверзија кај преодните предикати на внатрешни процеси во кои предметот на тој процес (емоција, мисла или физиолошка потреба) се реализира како (синтаксички) субјект во постглаголска позиција, како на пр.: $M u$

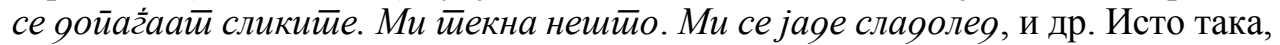
не се анализираат маркираните употреби на инверзијата каде што инверзијата е стилистичко средство, ${ }^{2}$ како на пример во (2).

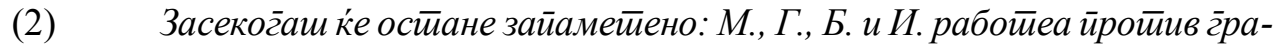

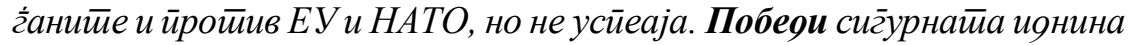

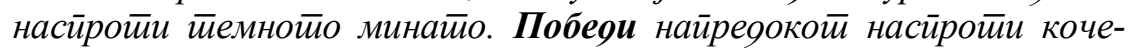

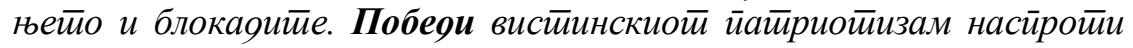

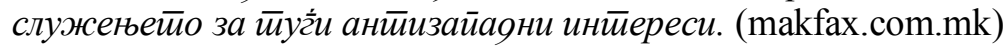

\footnotetext{
${ }^{2}$ Како што е случај со цитирање на директен говор по кој следува транзитивен глагол со субјект: „Каяе се йали светилойо?“ йраша Влаяо. (РБ) Таква инверзија е многу честа и во прозата на други јазици, на пример, во англискиот (Quirk et al. 1985: 881).
} 
За објаснување на причините за субјектна инверзија се потпираме на теоријата на информациската структура како што ја дефинира Ламбрехт (Lambrecht 1994), применувајќи го дискурсно-функционалниот пристап по примерот на Вард и Бирнер (Ward and Birner 2004). За таа цел собравме околу 300 реченици од различни текстови и ги класифициравме примерите според функцијата на инверзијата во нив и според глаголите со кои се јавуваат. Примерите се ексцерпирани од уметничка литература, академска проза, популарни и новинарски текстови на интернет, како и други примери од интернет. Во следниот дел се разгледуваат теориските поставки и се дефинираат основните термини. Понатаму во текстот се анализира собраниот материјал. Статијата завршува со заклучни забелешки, кои произлегуваат од анализата.

\section{2 Теориска рамка}

Во типолошката литература се смета дека во речениците со немаркирана информациска структура дискурсната функција на субјектниот референт е тема (која е прозодиски неистакната), ${ }^{3}$ а во ремата се наоѓа предикатот со кој се предицира нешто ново за темата. Комуникативниот фокус на реченицата, ${ }^{4}$ односно новата информација, може семантички да се провери со прашање што се однесува на предикатскиот израз (3). Исто така, ремата фонолошки се одредува според местото на реченичниот акцент, во потврдните реченици со карактеристична надолна мелодиска контура. Тоа значи дека во една реченица со немаркирана информациска структура тема - рема, темата е обележана со нагорна мелодиска контура, односно антикаденција, а ремата со надолна мелодиска контура. Знакот | ја означува границата меѓу темата и ремата.

$$
\text { ЛЈован } \mid \text { влезе во џсобайа. (Што направи Јован? Каде влезе Јован?) }
$$

Субјектниот референт Јован во (3) има тематски дискурсен статус, бидејќи им е познат на двајцата соговорници и е присутен во претходниот дискурс. Тука субјектот се совпаѓа со тема, носител на пресупонирана информација, позната на соговорниците. Но, субјектот и темата не се совпагаат ако субјектниот референт е нов во дискурсот, што подразбира дека претходно не бил споменат во текстот или логички не се подразбира од контекстот (Prince 1992). Дискурсно нов референт е оној што претходно не бил споменат или не се подразбира од контекстот.

\footnotetext{
${ }^{3}$ Прагматичко-синтаксичкото несовпаѓање се сигнализира со прозодиски, семантички и синтаксички показатели. Ако е субјектот интонациски и акцентски изделен, тој носи нова информација и имплицира контраст. Тој е фокален, интонациски изделен елемент, бидејќи ја изразува комуникативната цел на исказот, како на пр.: Јован влезе во собайа, а не Бојан. (Кој влезе во собата?). Тука фокусот на комуникацијата е аргументскиот израз во субјектна функција.

${ }^{4}$ Во англо-американската предметна литература не се користат термините 'тема' и 'рема' воведени од лингвистите на Прашката школа, туку 'топик' (пресупонирана информација) и 'фокус' (асерција, тоа што се комуницира).
} 
Ова прагматичко својство на референтот, познато како дискурсен или информациски статус, има две вредности: нов и стар/познат. Дискурсниот статус треба да се разликува од референцискиот статус на референтот. Вториот статус се определува од когнитивната способност на соговорниците да го идентификуваат (односно да го активираат) тој референт во меморијата, зависно од присуството на тој референт во текстот. ${ }^{5}$ Следствено, когнитивниот или референцискиот статус на референтот е скаларна вредност, која се движи од активен, полуактивен до неактивен статус (Givón 1983: 17-18; Chafe 1987: 22; Gundel et al. 1993: 278). Референцискиот статус може, но не мора да се совпаѓa со дискурсниот статус. Така, Јован во (4) е дискурсно нов и активен референт (референциски познат, па затоа е определен), а во (5) еgен човек е нов и неактивен (референциски непознат).

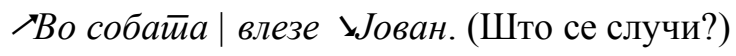

`Во собайа $\mid$ влезе еgен џчовек.

За да ја разбереме причината за субјектната инверзија треба да дадеме одговор на две прашања:

1. Како се вкрстуваат прагматичката улога на партиципантот на дејството со улогата што ја има во информациската структура?

2. Како се вкрстуваат синтаксичката и прозодиската структура на реченицата?

Според Ламбрехт (Lambrecht 1994: 165), активен и познат референт најлесно се избира како тема, а најнеприфатлив кандидат за тема е нов референт. При поврзување на прагматичките и синтаксичките релации на реченицата со комуникациски важен субјектен партиципант, настанува инверзија на субјектот. Според Ламбрехт (Lambrecht 1994: 22), инвертиран субјект може да се дефинира како субјект со рематичен информациски статус. Такви субјекти најчесто среќаваме во презентациски реченици, кои се „специјализирани“" конструкции за воведување нов референт во дискурсот. Презентациските реченици немаат тема (некој референт), па не може да се зборува за прототипна информациска структура тема - рема. Така, реченицата: Вo

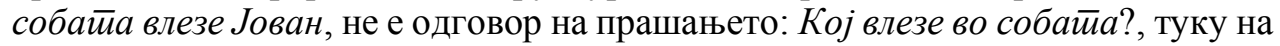
прашањето: Шӣо се случи? Ламбрехт (Lambrecht 1994: 144) смета дека ваквите реченици се поттип на т.н. тетиски пропозиции, ${ }^{6}$ кои соопштуваат за случување на некој настан, а не што му се случило на партиципантот на настанот. Примерите во (6) не може да се поделат на информациски делови нова и стара информација (целата реченица е нова информација), и затоа одговараат на прашањето: Шйо се случува/се случи? или: Шӣо йи е?

\footnotetext{
5 Тоа во јазикот се рефлектира со избор на различни анафорски средства. За анафорските форми на субјектот во македонскиот јазик види кај Бужаровска и Митковска (2018).

${ }^{6}$ Thetic propositions (Lambrecht 1994).
} 
Така, Јован во (4) им е познат на соговорниците, но не е споменат претходно во овој дискурс, па според тоа не е тема. За споредба, во прагматички немаркирана реченица со иста пропозициска содржина во (3) субјектниот референт претставува позната информација, претходно спомената во текстот и затоа субјектот, како тема, ја зафаќа каноничната предглаголска позиција. Забележуваме дека примерите (3) и (4) имаат иста интонациска, но различна информациска структура: Јован е тема во (3) Јован влезе во собайа, а рема во (4) Во собайа влезе Јован. Прилошкиот израз во собайа е рема во (3), а според синтаксичката позиција и нагорната интонација би требало да е тема во (4). Постојат различни ставови во предметната литература во врска за статусот на почетната определбата во почетна реченична позиција, но за тоа ќе зборуваме понатаму.

Сметаме дека и прозодиската структура ја открива информациската структура и затоа во некои примери (кои не се од примерокот) го бележиме акцентот. Во (6) реченичниот акцент со надолна мелодиска контура, односно каденција, ${ }^{7}$ паѓа на глаголот, додека субјектот е прозодиски неутрален (обележан со нула). Тоа укажува дека овие реченици немаат тема, односно не се делат на тема - рема.

а. $\quad$ Овони ьйелефоной. (Што се случи?)

б. Дојре џмарко. (Што се случи?)

Тетичките пропозиции може да се формализираат во два вида реченици зависно од комуникативниот фокус: презентациски и реченици-случки. ${ }^{8}$ Првите воведуваат нов партиципант како во примерот (4), додека вторите (6) воведуваат нов настан (Lambrecht 1994). Во овој тип реченици инверзијата служи да го фокусира вниманието на слушателот/читателот врз субјектниот референт. Во речениците-случки фокусот се преместува на самиот настан: се искажува информација дека се случил некој настан во кој партиципантот учествувал

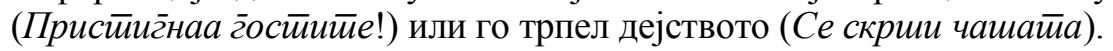

Се чини дека самата структура на првиот тип реченици е погодна за презентациската функција. Тие „создаваат“ сцена на која се појавува партиципантот на дејството, а тоа имплицира дека на него се насочува фокусот на вниманието. Таквата конструкција типично се состои од прилошка определба, која ја поставува сцената на настанот/ситуацијата, а по неа следуваат глаголот и субјектот. ${ }^{9}$ Носителот на главниот реченичен акцент е новововедениот партиципант во раскажувањето, за кој се очекува да стане збор во следната реченица.

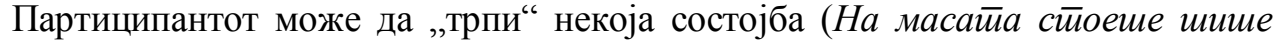

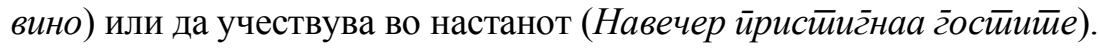

\footnotetext{
${ }^{7}$ Подетално за реченичниот акцент и мелодиските контури во македонскиот јазик кај Савицка и Спасов (1997).

${ }^{8}$ Eventive constructions (Lambrecht 1994).

${ }^{9}$ Истата презентациска функција на инверзијата во форма на конвенционализирани изрази се користи за почнување на приказни: Си бил еgен човек..., Преg многуу гоояини си живеел еgен иар....
} 
Поради својата прагматичка функција презентациските конструкции наложуваат семантички рестрикции во изборот на предикатите. Со оглед на тоа што таквите реченици кодираат пропозиции кои потврдуваат постоење на некој ентитет, тие избираат непреодни глаголи што означуваат присуство (7), појавување (8) или исчезнување (9).

\section{Во невербална комуникачија сӣаг்̃ и начиной на облекување. (BН)}

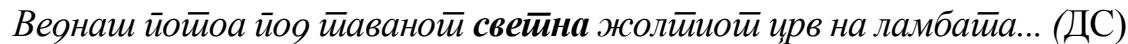

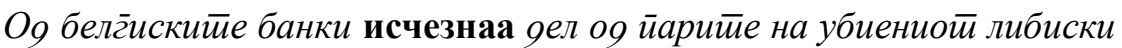
лиоер Муамер Гаяафи. (mia.mk/2018/10/r)

Во предметната литература непреодните глаголи се делат на две поголеми групи: т.н. неакузативни (декаузални) и неергативни. ${ }^{10}$ Меѓусебно тие се разликуваат според семантичката улога на единствениот партиципант: кај неакузативните тој не е агенс, туку трпител на дејството (сфатен широко), а кај

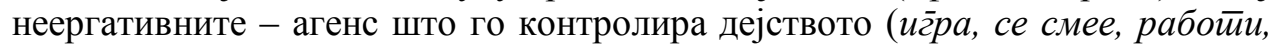
иллива, скока и сл.).

Неакузативните ${ }^{11}$ глаголи означуваат декаузални дејства од два типа: (a) некоја промена што се случува со партиципантот без негово дејствување, или пак (б) промена на место на партиципантот (кај глаголите за егзистенција и за движење gojge, йристиигене, излезе и сл.). ${ }^{12}$ Дејствата од типот (а) во македонскиот јазик најчесто се изразуваат со медијални глаголи со рефлексивен маркер (се скрии, се измесйи, се йојави).

Меѓутоа, неакузативните и неергативните глаголи не претставуваат две сосема издвоени класи. Според Ваз Тајшајра (Vaz Teixeira 2018), истражувањата покажуваат дека не е секогаш можно глаголите категорички да се класифицираат во едната или во другата група според одредените критериуми. Некои покажуваат повеќе совпаѓање со едната, а други со другата група, а некои имаат средни особини. Поради тоа, некои автори сметаат дека постои континуум на интранзитивни дејства, кој се движи од крајна неакузативност (промена на место и состојба) до крајна неергативност (контролирани дејства на движење и на недвижење). Покрај тоа, некои глаголи може да имаат повеќе варијанти на значење, кои не припаѓаат во една класа, а и контекстот во кој се употребени глаголите може да влијае на тоа тие да добијат понеакузативни или понеергативни особини. Според тоа, сметаме

\footnotetext{
${ }^{10}$ Разликата меѓу неакузативните и неергативните глаголи е првпат дефинирана во т.н. Хипотеза за неакузативноста на Перлмутер (Unaccusative Hypothesis, Perlmutter 1978) и детално анализирана за англискиот јазик во Левин и Рапапорт Ховав (Levin and Rappaport Hovav 1995). 11 Овој термин, и покрај нетраспарентноста, е широко прифатен во лингвистиката (посебно англојазичната), но не е познат во домашната литература.

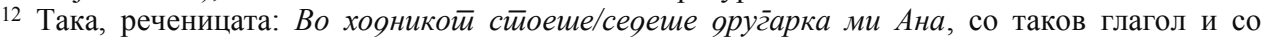
неагентивен субјект е општоприфатлива. Но, слична реченица со агентивен („неергативен“) глагол во кој агенсот го предизвукува дејството без да имплицира појавување е необична: Вo хояникой рабойеше/иг̄раше/се смееше/скокаше яруг̄арка ми Ана.
} 
дека самата инвертирана конструкција и презентациската дискурсна функција може да доведат до тоа глаголот да се толкува како неакузативен, што значи помалку агентивен.

Покрај овие два типа глаголи, овие конструкции се градат и од пасивни конструкции од преодни глаголи. Причината е во тоа што речениците со инверзија обично изразуваат ситуации во кои партиципантот во позиција на субјект нема активна улога, а за тоа се погодни пасивните конструкции, како што се (10) и (11).

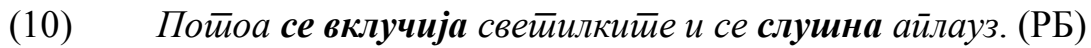

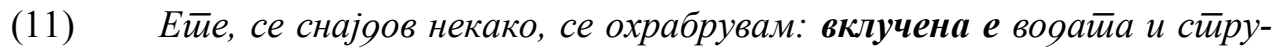
јайа, ойворени се йрозориийе и ќеиеенцитее... (РБ)

\section{3 Анализа на македонските примери: семантиката на предикатот}

Во предметната литература забележана е корелација меѓу субјектната инверзија и одредени непреодни глаголи што го дозволуваат тоа. Како што споменавме погоре, во анализираните конструкции најчесто се среќаваат декаузални глаголи, познати како неакузативни, чие основно значење е да означат дека некоја промена се случува со партиципантот без негово дејствување. Се смета дека само „неакузативните“ глаголи дозволуваат инверзија, за разлика од втората група каузални непреодни глаголи, познати како неергативни.

Класата на неакузативните глаголи според лексичкиот аспект се дели на две поткласи, кои семантички не се хомогени (Levin and Rappaport Hovav 1995: 221). Во нашиот примерок застапени се следниве глаголи:

а. глаголи што имплицираат промена - во едната подгрупа се глаголите за неконтролирани дејства: се случи, настиане, се йојави/јави, исчезне, йочне, ирооолжи, заврши, умре, се рояи, йаяне (12), а во другата глаголи што изразуваат движење на ентитетот кон „сцената“ на дејството или од неа:

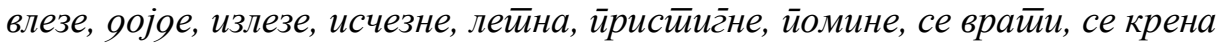
и сл. (13).

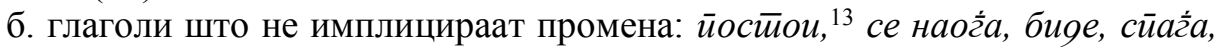
живее, иеече, или изразуваат позиција/ставот на телото на ентитетот: сеgи, стиои, лежи, виси, остиане (14).

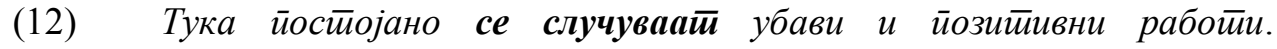
(http://www.fashionel.mk/intervjua)

(13) На ова местио йорано поминуваше возой кој ояеше яо Кичево. Денес

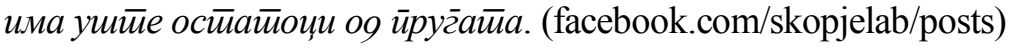

${ }^{13}$ Глаголот йосӣои во нашиот примерок се јавува само со инвертиран субјект. 


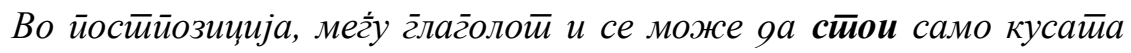
заменска форма за иноирекиенн објекй. (ЛМ)

Медијалните (15) се-конструкции, кои имплицираат дека субјектниот ентитет се појавува или се наоѓa на сцената (се шири, се йростиира, се крие, се крева, се ойвора, се зайвора, се йойи, се суши, се слуша, се гллеяа и сл.), семантички се однесуваат како декаузални непреодни глаголи, бидејќи се непреодни и субјектниот референт има улога на трпител. Но, најважно е што нивната основна комуникативна функција е да соопштат што се случува бидејќи ,...тие ја покажуваат финалната фаза од каузалниот процес и акцентот го ставаат врз процесот што се одвива во/со референтот во улога на трпител“ (Митковска 2011: 119), а тоа повлекува инверзија на субјектот. Затоа, како централни предикати во инверзираните конструкции се јавуваат медијалните $c e$-конструкции, кои ја покажуваат финалната фаза од каузалниот процес и акцентот го ставаат врз процесот што се одвива со референтот трпител. Од друга страна, основната функција на пасивните $c e$-конструкции (16) е апстрахирање на агенсот од дејството, „а со тоа самата активност добива најголема комуникативна важност (Митковска 2011: 102). Со тоа пасивот (се-пасивот и перифрастичниот сум-пасив) се наметнува како средство за истакнување на настанот.

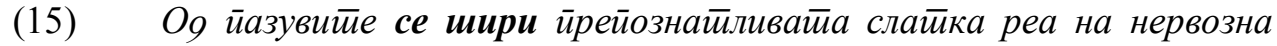
$\bar{u}$ oū. (РБ)

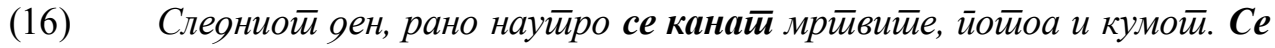

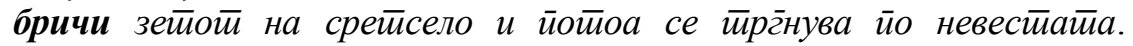
(netpress.com.mk)

Сепак, најдовме примери со презентациски конструкции што не се градени со т.н. неакузативни глаголи. Тоа говори во прилог на хипотезата дека самата конструкција внесува презентациско значење во, инаку, неергативните глаголи (како што потврдува и Mendikoetxea 2006). Иако йрча не подразбира статична состојба на субјектот во (17), значењето на присуство е истакнато поради сцената на настанот (во Охрия). Всушност, се йрчаше во насловот на написот во (17) значи 'се одржа', што се гледа во првата реченица (18) од истиот напис.

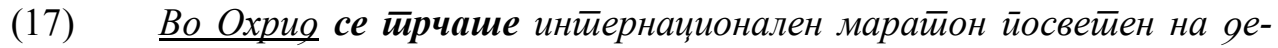

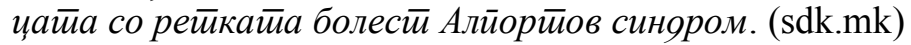

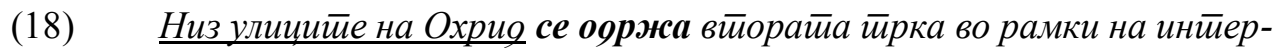

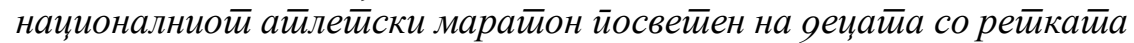
болести Алйорӣов синором. (sdk.mk) 
Но, неакузативните глаголи се јавуваат и во немаркираната информациска структура тема - рема (19 и 21). Тоа покажува дека инверзијата не е предизвикана од семантиката на глаголот, туку од прагматиката на презентациската конструкција или на реченицата-случка (20 и 22).

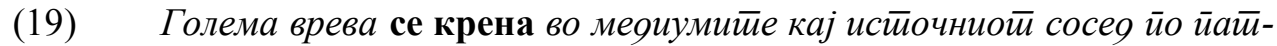

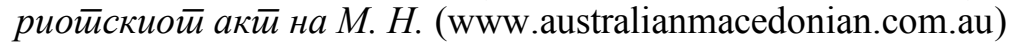

(20) П Прео неколку дена се крена огрромна врева за човекой кој йаниувал og срие. (kafepauza.mk)

(21) Снег̄ō̄ падна и яонесе йроблеми. (gradskiparking.com.mk)

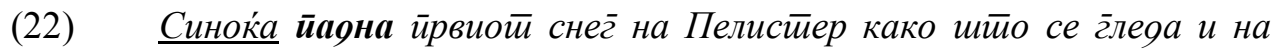

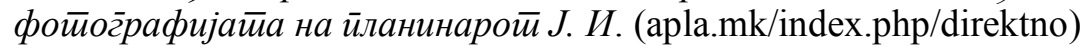

Некои автори сметаат дека глаголите што дозволуваат инверзија се семантички сиромашни: не се информативни, не кажуваат нешто ново за партиципантот (Levin and Rappaport Hovav 1995: 230, Bentley et al. 2015: 216). He оспоруваме дека некаузативните глаголи се најпогодни за градење презентациски конструкции, но сметаме дека за таквото семантичко избледување е одговорна самата презентациска функција на конструкцијата, која го „нама-

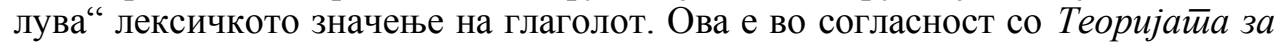

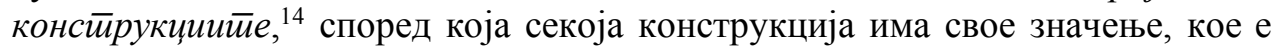
поврзано со значењето на составните елементи (но, не е нивни збир). ${ }^{15}$

\section{4 Дискурсни фактори на ниво на реченицата}

Според Даунинг и Лок (Downing and Locke 2006: 228), презентациските конструкции претставуваат когнитивно средство со кое се внесува нов дискурсен учесник во свеста на слушателот/читателот. Целта на воведувањето на нов референт во дискурсот е да се потврди неговото присуство на одредена локација (Bentley et al. 2015: 48) и, следствено, имплицира место каде што тој се појавува. Затоа во иницијалната позиција на презентациските конструкции типично стои некоја околност на дејството (кодирана со локативен и временски прилошки израз), што ја поставува сцената на која се одвива дејството. Тоа

\footnotetext{
${ }^{14}$ Construction Grammar (Goldberg 2005).

15 Тие елементи ги обединува некое својство, но во конструкцијата може да влезат и други елементи со приспособување кон структурата на конструкција. Притоа, нивното значење може да се промени, но со почеста употреба и тие може да влијаат конструкцијата да ја прошири својата функционална зона. Ако дадената конструкција во еден јазик „дозволува“ поширок опсег на елементи, тоа значи дека се наоѓa на повисок степен на граматикализација од слична конструкција во друг јазик, која има поконзервативен избор на елементи. Повеќе за тоа види кај Голдберг (Goldberg 2005).
} 
значи дека местото на локативната (или темпоралната) определба на почетната реченична позиција е прагматички мотивирана и ја определува синтаксата на конструкцијата: определба + предикат + субјект. Во неа предикатот и субјектот се јадрото на конструкцијата (нова информација), додека определбата ја поврзува реченицата со претходниот текст, но истовремено, служи како вовед во нова тема на ниво на текстот (23).

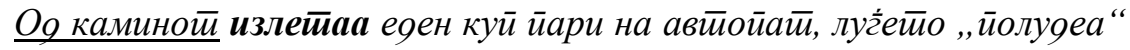
$u$ настана голем урнебес. (eall fans.com/od-kaminot)

Во собраните примери од примерокот доминантно е присуството на определбата на почетокот на реченицата. Тоа е најчесто локативна определба (24 и 25), но може да биде временска (26) или да стојат и двете (27).

$$
\text { Во г̄лавайа на Бојан му се реоай мислииее... (ГП) }
$$

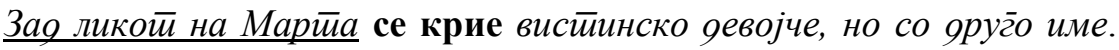
(hashtag.mk)

По неа се йрейсийвија и яруг̄ите жени. (РБ)

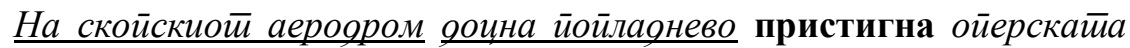
оива Елена Мошук. (ohridskoleto.com.mk)

Во почетна реченична позиција може да се најде и топикализиран конституент или некој текстуален сврзник (на пр., адверсативното сейак), со кој тематски се надоврзува реченицата со претходниот текст (28).

Сейак меѓу формийе и лексемитее иоосӣои еяна многуy важна разлика... (ЛМ)

Некои автори мислат дека информациската улога на иницијалната прилошка определба е посебен вид тема со која почнува нов дискурс (Bentley et al. 2015: $63)$ или дека „околностите“"16 имаат функција на реченична тема во иницијална позиција (Downing and Locke 2006: 222, 259). Ист став има и Падучева (2016). Другите автори не се изјаснуваат категорично за информацискиот статус на иницијалната определба, иако истакнуваат дека таа има, пред сѐ, дискурсна улога на ниво на целиот текст, поставувајќи ја сцената за воведување на новиот субјектен референт. Квирк и др. (Quirk et al. 1985: 522) тврдат дека конституентот во почетна реченична позиција креира драмски ефект - очекување што ќе следува понатаму. Бирнер (Birner 1996), разгледувајќи ја улогата на инверзијата во организирање на информацијата на реченично и на текстуално ниво од дискурсно-функционален пристап, доаѓ до заклучок дека

\footnotetext{
${ }^{16}$ Circumstantial adjuncts (Downing and Locke 2006).
} 
иницијално поставената определба служи за потребите на информациската структура, бидејќи содржи постара информација од информацијата што ја носи постглаголскиот субјект.

Ние сметаме дека е тоа непрототипна тема, која ја нарекуваме „сценска тема“, бидејќи не посочува на партиципант, туку на околност. Индиректен доказ дека иницијалната определба, сепак, има функција на тема, е прозоди-

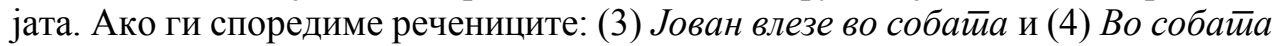
влезе Јован, ќе видиме дека имаат иста прозодија и дека определбата во собайа во (4) се одликува со нагорна интонација исто така како Јован во (3).

Во собраниот примерок има и ретки примери без определби во презентациската конструкција. Нивното отсуството може да се објасни со дејствувањето на дискурсните фактори на ниво на текстот. Таквите реченици се среќаваат во реклами (29), во новинарски наслови (30) или почетни реченици на новинарски текстови (31).

(29) Присийиг̄на новата епизода на Фчерашни. (fn.mk)

(30) Исчезна 14-годишно девојче од Битола. (sudstvo.mk)

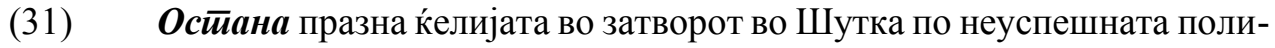
циска потера по екс премиерот. (telma.com.mk/ostana-prazna-kelijata)

За синтаксичка инверзија на субјектот со глаголот многу важен фактор е информацискиот статус на субјектниот референт: тој мора да биде нов во дискурсот. Анализата на собраните примери покажа дека различниот референциски статус на референтот (идентификуван или неидентификуван) не игра важна улога за инверзијата. Не е важно дали субјектните референти веќе постојат во меморијата на соговорниците (т.е. ментално се достапни), важно е што конструкцијата соопштува дека тие се нови во однос на овој контекст (Bentley et al. 2015: 47). ${ }^{17}$ Исто така, Јован во: Во собайа влезе Јован им е познат на двајцата соговорници за разлика од еgен човек: Во собайа влезе еgен човек, но и двата субјекта стојат по глаголот, бидејќи нивните референти првпат се споменуваат. И во (32) субјектот е определен, но нов во дискурсот, што се гледа од определбата „досега за нас сеништен призрак“.

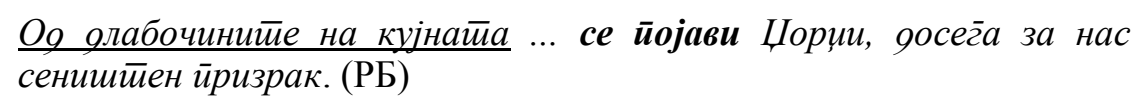

Сепак, најдовме ретки исклучоци во нашиот примерок кога референтот на постглаголскиот субјект не е сосема нов партиципант. Тоа може да се објасни со дискурсната улога што ја има субјектната инверзија на ниво на текстот. Во

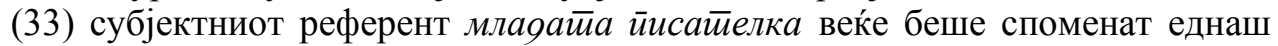

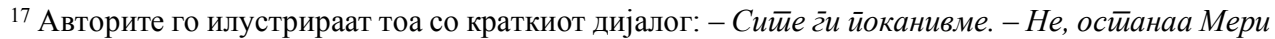
и Пол.
} 
порано во текстот, но тука таа повторно се воведува за да почне нова тематска целина поврзана со почетокот на приредбата. ${ }^{18}$

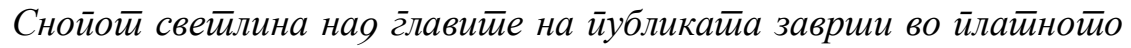
на сценайа на кое сег̄a стиоеше исйишано EMPOWERING WOMEN,

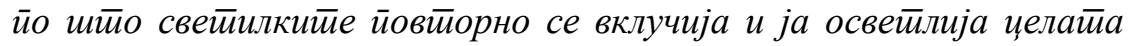

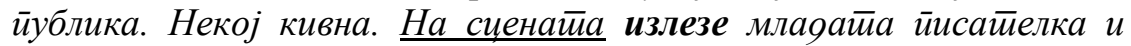

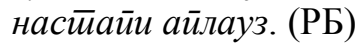

Од ова произлегува дека немаркираната информациска структура (тема рема) тежнее да се реализира со идентификувани и познати референти во предглаголска субјектна позиција (како тема), додека презентациските конструкции главно се реализираат со нови субјектни референти во постглаголска позиција, кои често се неидентификувани, како во (34).

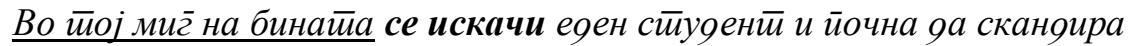
на микрофон. (РБ)

Во каноничната субјектна позиција се избегнува да се става дискурсно нов

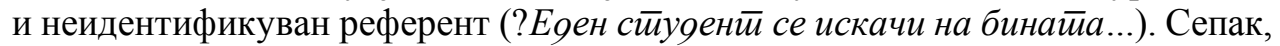
најдовме неколку спротивни примери, каде што овој принцип се нарушува поради дискурсната улога на таквиот субјект: неговиот референт е периферен учесник, кој обично се јавува во кратки секвенции. Тука немаме презентациска конструкција, која воведува нов учесник во дискурсот, импликувајќ́ дека тој понатаму може да биде важен во наративот, посебно ако се работи за одушевени протагонисти. Во (35), во третата реченица, еяна жена е тема само во две последователни реченици, па така, не ја прекинува тематската кохерентност на овој сегмент од текстот. Во (36) реченицата со неопределен и нов субјект (еgна залуйана срна) логички се надоврзува на претходната како еден вид објаснување, но во следната реченица протагонистот е пак Бојан.

Ја зеое йовйорно в раце, ја лег̄на и ѝ ја йоgаяе левайа оојка. Ева ја лайна и веонаш замолче. Еяна жена се йојави на скалилайа. Ја

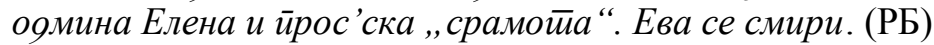

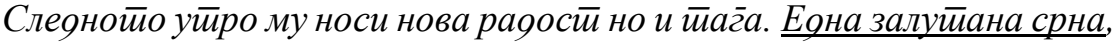
со йовредена ног̄a, заг̄лавила во снег̄ō̄. Бојан ја ослобояува оя снег̄ō̄, ја носи оома, се гррижи за неа. (ГП)

Има и друга причина за употребата на неопределени субјекти во почетна позиција. Прифатливоста на (36) веројатно се должи на различната информациска структура, која ја суспендира презентациската функција. Во примерот (37), пак, бидејќ и фокусот на комуникацијата паѓа на предикатот, реченицата има

\footnotetext{
18 Можноста за повторно воведување на претходно нов референт понатаму во текстот ја забележува Бреснан (Bresnan 1994: 86), нарекувајќи го „презентациски фокус“.
} 
информациска структура тема -рема: соопштува што направил еден непознат и нов референт. Новиот референт е помалку важен за приказната отколку самата приказна и затоа таквата употреба се забележува во анегдоти. ${ }^{19}$

Еоен човек влезе со нож во рака во йолицииска сйаниц̧а, а йолиц̧а-

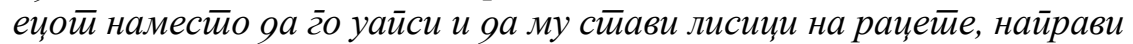

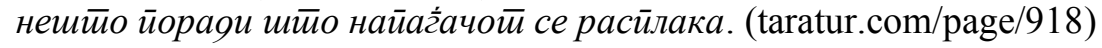

\section{5 Дискурсни фактори на ниво на текст во функционални стилови}

Во претходните поглавја веќе беше спомената улогата на дискурсните фактори на ниво на текст кои влијаат врз суспендирањето на очекуваната субјектна инверзија во реченицата. Следејќи ги Ворд и Бирнер (Ward and Birner 2004), сметаме дека инверзијата служи за организирање на информацијата на реченично и на текстуално ниво, истакнувајќи ја улогата на презентациските конструкции во градењето на текстот.

Посебно е важна улогата на „околност“ на опишана ситуација или дејство кодирана со прилошка определба во почетна реченична позиција. Нивната дистрибуција зависи од жанрот на пишаниот текст (Prado Alonso 2007). Co оглед на тоа што прозните дела опишуваат настани во простор и време, тие содржат определби што го даваат потребниот контекст во кој е сместена опишаната ситуација. Видовме дека во презентациските конструкции како „сценски“ теми најчесто се употребуваат локативни определби, по нив следуваат временски (или комбинација на двете). Во (38) раскажувањето за случката во минатото почнува со воведување на главниот протагонист со давање темпоралната рамка на случката, а во втората реченица се воведуваат и другите двајца учесници преку реферирање на средба што се подразбира од контекстот. Инверзијата создава очекување дека раскажувањето ќе продолжи и дека ќе следуваат други настани.

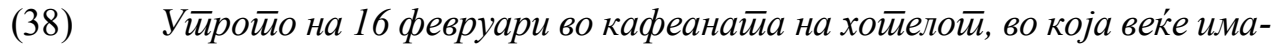

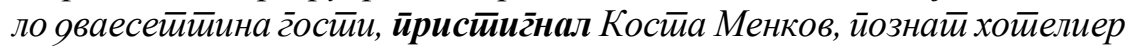

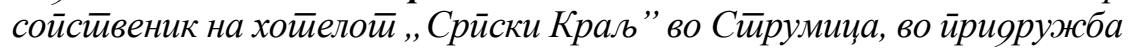
со Илија Пейровиќ, сойсиивеник на винскиой йоррум „, Фрушка Гора” во Скойје. На среобайа оошле и Анге́л Пой Ѓ рчев, закуйец на хойелой „Југ̄ословенска круна”, и Вујица Мојсиловиќ, засӣайник на филијалайа на Сараевскайа ӣиварница во Скойje. (fashionel.mk/intervjua)

Субјектната инверзија може да послужи и за менување на претходната тема (Kreyer 2004) преку воведување нов учесник за кој се раскажува во пократка епизода. На тој начин се постигнува поврзување на релативно нова

\footnotetext{
${ }^{19}$ Една жена влезе во продавницата за да си најде сопруг. На првиот кат на влезот има натпис: „Овие мажи имаат работа.“ (kukuriku.com.mk)
} 
информација со претходниот контекст, што придонесува за градењето на текстот. Во (39) раскажувањето за протагонистката се прекинува со воведување периферен учесник (шофер) за да се засили ефектот од неприсуството на Драган, кој, пак, се појавува во следната реченица.

Во следниот пример (40) промената на тема е неочекувана, но се потврдува ставот на Ворд и Бирнер (Ward and Birner 2004: 240) дека воведениот партиципант од презентациската конструкција станува тема во понатамошниот дискурс (во реченицата со директен говор).

(39) Се наяеваше gека ќе г̄o вияи Драг̄ан како ја чека йокрај ог̄раяайа. Но йаму расчекорено сииоеше еден йосйан и йажен чичко - иофер

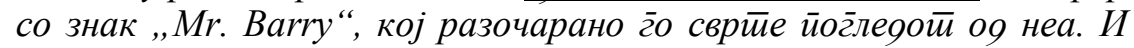
наявор Драг̄ан г̄о немаше. (РБ)

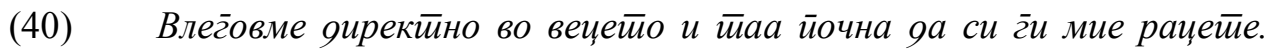

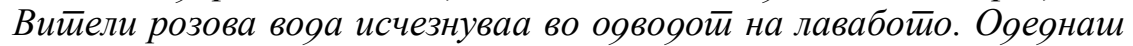

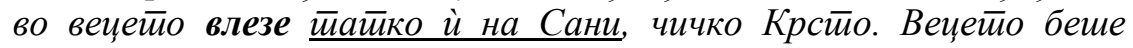
ирремалечко за нас йројија. Се залейив за каяайа зая мене. „Пак ли, мори козо, си берела кайини? “ ѝ се развика йој. (РБ)

Во академските текстови преовладуваат пасивните конструкции (со отсутен агенс и субјект трпител), со кои тематски се врзуваат речениците. Исто така, почесто се јавуваат презентациски конструкции во кои иницијалните локативни определби не означуваат физички простор, туку дискурсен, на пр., областа на проучувањето (41), а како воведни елементи се јавуваат топикализирани изрази (42).

(41) Соржинскийе еоиници се йоgелени на gва gела кои лог̄ички се наяо-

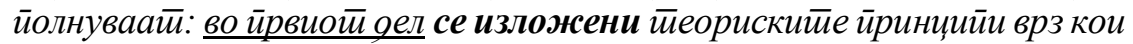

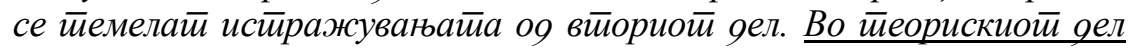

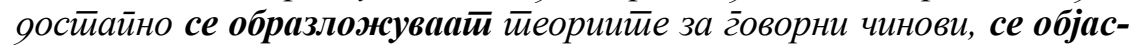

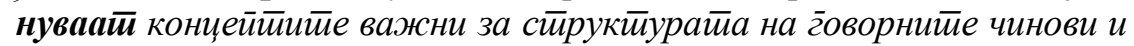

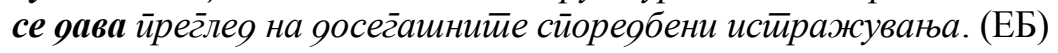

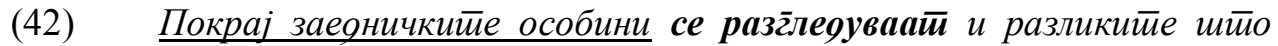

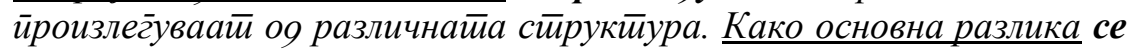

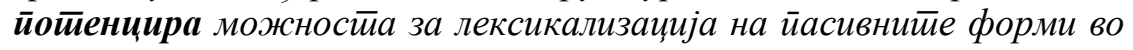
еоен вия лексички се-консӣрукциии. (ЛМ)

Горните примери покажуваат дека во академскиот дискурс инверзијата има главно кохезивна улога. Но, и во уметничката литература и во академските текстови забележавме дека инверзијата служи за управување на фокусот на вниманието на читателот/слушателот преку промена на темата. На тој начин инверзијата придонесува за поцврста структура на текстот, што е посебно изразено во академскиот стил (Prado Alonso 2007: 168, 177). 
Што се однесува до уметничката проза, субјектната инверзија има и прагматичка функција: таа му припишува важен дискурсен статус на субјектниот референт и создава ефект на непосреден сведок на настаните. Самата презентациска конструкција, со тоа што воведува нов партиципант во текстот, имплицира дека тој ќе биде тема на понатамошниот дискурс, што се гледа во примерите погоре (38-40).

Втората прагматичка функција на инверзијата се пројавува во креирањето илузија кај слушателот/читателот дека е непосреден сведок и директно ја перципира опишаната ситуација (43), односно како да ја гледа на филм со камера што се движи кон дадената сцена (Doergeloh 1997: 111; Biber et al. 1999: 955; Kreyer 2004: 191).

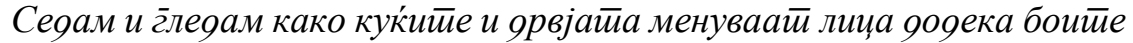
мояреати и сенкийе се заяебелуваай. Еяна йочка свейнува яолу на

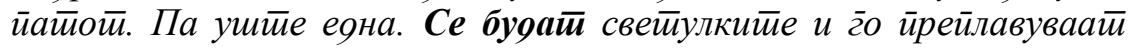

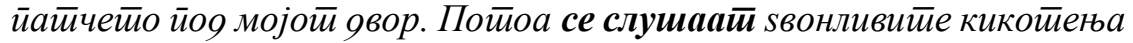

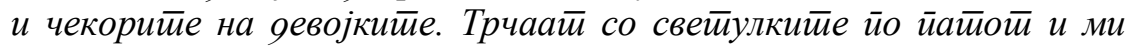

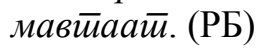

\section{6 Заклучок}

Во статијата ги испитавме претпоставките за субјектната инверзија во македонскиот јазик. Таа се појавува во простата реченица градена од интранзитивни, т.н. неакузативни глаголи. Врз база на автентичен јазичен материјал утврдивме дека причините за субјектната инверзија се должат на заемодејството на прагматичките фактори што дејствуваат на реченично ниво со факторите на текстуално ниво. Утврдивме дека речениците со инверзија се одликуваат со маркирана информациска структура, која потекнува од нивната дискурсна функција: тие воведуваат нов партиципант или нова случка во текстот. Субјектниот референт, како нов ентитет, нема дискурсен статус на тема и се преместува по глаголот. Покажавме дека самата функција на презентациска конструкција ги граматикализира семантичката и прагматичката улога на субјектниот партиципант, избледувајќи го значењето на глаголскиот предикат. Инверзијата со неакузативен глагол може да биде ,поништена“ под влијание на факторите на текстуално ниво, како на пример, функцијата на дадениот исказ.

Исто така, ја испитавме функцијата на инверзијата на ниво на текст и утврдивме дека таа има кохезивна и прагматичка функција. Првата служи за менување на тема во помала секвенција, но и меѓу поголеми текстуални единици, со што придонесува за поцврсто и пологично структурирање на текстот. Од друга страна, прагматичката функција ја среќаваме во литературните дела каде што инверзијата му припишува важен дискурсен статус на субјектниот референт, внесува извесна драматика и создава непосредна сликовитост во нарацијата. 


\section{Библиографија}

Бужаровска, Е. и Митковска, Л. (2018). Реализација на анафорскиот субјект во македонскиот јазик. Современа филолог̄uја, 1(2): 29-50.

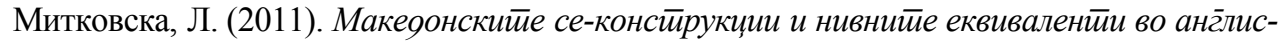
киой јазик. Скопје: Македонска реч.

Падучева, Е. В. (2016). Коммуникативная структура и линейно-акцентные преобрзавания предложения. Архитектура клаузы в параметричеких моделях. А. В. Циммерлинг, Е. А. Лютикова (ур.). Москва: Издательский Дом ЯСК.

Савицка, И. и Спасов, Љ. (1997). Фонолог̄ија на современиой макеяонски сӣаняароен јазик. Скопје: Детска радост.

Bentley, D., Ciconte, F. M. and Cruschina S. (2015). Locatives in Romance dialects of Italy. Oxford: Oxford University Press.

Biber, D., Johansson, S., Leech, G., Conrad, S. and Finegan, E. (1999). Longman grammar of spoken and written English. London: Longman.

Birner, B. J. (1996). The discourse function of inversion in English. New York/London: Garland.

Bresnan, J. (1994). Locative inversion and the architecture of universal grammar. Language, 70 : $72-131$.

Chafe, W. L. (1987). Cognitive constraints on information flow. In R. S. Tomlin (ed.). Coherence and grounding in discourse, 21-52. Amsterdam: John Benjamins.

Comrie, B. (1989). Language universals and language typology. Oxford: Blackwell.

Doergeloh, H. (1997). Inversion in modern English: Form and function. Amsterdam: Benjamins.

Downing, A. and Locke, P. (2006). English grammar: A university course. New York: Routledge.

Givón, T. (1983). Topic continuity and word-order pragmatics in Ute. In T. Givón (ed.). Topic continuity in discourse, 145-195. Amsterdam: John Benjamins.

Givón, T. (2001). Syntax: An Introduction, Vol 2. Amsterdam: John Benjamins.

Goldberg, A. D. (2005). Constructions at work: The nature of generalization in language. Oxford: Oxford University Press.

Gundel, J. K., Hedberg, N. and Zacharski, R. (1993). Cognitive status and the form of referring expressions in discourse. Language, 2: 274-307.

Kreyer, W. (2004). Inversion in modern written English: Syntactic complexity, information status and creative writer. Doctoral dissertation. University of Bonn.

Lambrecht, K. (1994). Information structure and sentence form: Topic, focus, and the mental representation of discourse referents. Cambridge: Cambridge University Press.

Levin, B. and Rappaport Hovav, M. (1995). Unaccusativity. Cambridge, MA: MIT Press.

Mendikoetxea, A. (2006). Unergatives that become unnacussatives in English locative inversion structures: A lexical-syntactic approach. In C. Copy and L. Gournay (eds.). Points de Vue sur l'Inversion. Cahiers de recherché en Grammaire Anglais l'Enonciation, Tome 9, 133155. Paris: Editions Orphys.

Rutherford, W. E. (1989) Interlanguage and pragmatic word order. In S. M. Gass and J. Schachter (eds.). Linguistic perspectives in second language acquisition, 163-182. Cambridge: Cambridge University Press.

Perlmutter, D. M. (1978). Impersonal passives and the unaccusative hypothesis. Annual Meeting of the Berkeley Linguistics Society, 34: 157-187.

Prado Alonso, C. (2007). Inversion in written and spoken contemporary English. Doctoral dissertation. University of Santiago de Compostela. 
Prince, E. F. (1992). Subjects, definiteness, and information-status. In W. C. Mann and S. A. Thompson (eds.). Discourse description: Diverse linguistic analyses of a fund-raising text, 295-325. Amsterdam: John Benjamins.

Quirk, R., Greenbaum, S., Leech, G. and Svartvik, J. (1985). A comprehensive grammar of the English language. London: Longman.

Vaz Teixeira J. A. (2018). L2 acquisition at the interfaces: Subject verb inversion in L2 English and its pedagogical implications. Doctoral dissertation. Universidade Nova de Lisboa.

Ward, G. and Birner, B. J. (2004). Information Structure and Noncanonical Syntax. In L. R. Horn and G. Ward (eds.), The handbook of pragmatics. Oxford: Basil Blackwell, 153-174.

\section{Извори и скратеници}

ЕБ Бужаровска, Е. (2014). Рецензија за Говорни чинови во макеяонскиот̄ јазик од М. Кусевска, 3. Трајкова, С. Нешковска и Ф. Смичковска. Скопје: Академски печат.

РБ Бужаровска, Р. (2018). Не ояам никаяе. Скопје: Или-или.

ГП Поповски, Г. (2004). Бојан. Скопје: Детска радост.

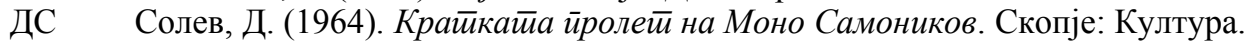

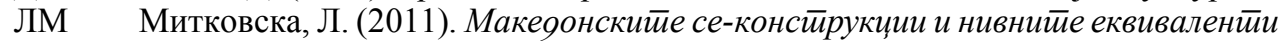
во анг̄лискиой јазик. Скопје: Македонска реч.

ВН Николовска, В. (2012). Кулйура на изразувањет̄о. Достапно на: eprints.ugd.edu.mk/3163 [Пристапено на: 2.12.2018] 